\section{Dinamika Pengelolaan Dana Desa dan Pembangunan Berbasis Prioritas Dalam Penyusunan APBDes}

\author{
Adie Dwiyanto Nurlukman 1), Fadly \\ Fadillah Said 2) \\ 1) Program Studi Ilmu Pemerintahan, \\ Universitas Muhammadiyah Tangerang, \\ Indonesia. \\ 2) Program Studi Ilmu Pemerintahan, \\ Universitas Muhammadiyah Tangerang, \\ Indonesia.
}

*Korespondensi Penulis. E-mail: fadly.said99@gmail.com

\section{Abstrak}

Diberlakukannya Undang-Undang No. 6 Tahun 2014 membuka peluang bagi desa dalam proses percepatan pembangunan melalui alokasi dana desa. Melalui pengelolaan dana desa yang baik dan berbasiskan kepada konsep Good Governance, diupayakan penggunaanya memenuhi kaidah transparansi, partisipasi, dan akuntabilitas sehingga berdampak kepada prioritas dan kebutuhannya dalam pembangunan desa. Penelitian ini mencoba menganalisis proses pengelolaan dana desa dengan pendekatan perencanaan pembangunan berbasis prioritas dan kebutuhan dalam mekanisme penyusunan APBDes. Metode yang digunakan dalam penelitian ini adalah metode deskriptif dengan pendekatan kualitatif melalui teknik koleksi data melalui wawancara. Lokasi penelitian ini berfokus kepada perencanaan pembangunan yang dilakukan di Desa Sukadiri, Kabupaten Tangerang. Penelitian ini menemukan penyusunan APBDes dilakukan dengan melibatkan

semua elemen dan aspirasi masyarakat mengenai kebutuhan mereka dengan berpedoman dengan RPJMDes agar terjadi kesinambungan dari programprogram kerja pemerintah desa setiap tahunnya. Hal yang sangat disayangkan adalah tidak adanya upaya dari Pemerintah Desa Sukadiri untuk mendapatkan dan meningkatkan pendapatan asli desa.

Kata Kunci: Dana Desa, Perencanaan Pembangunan, Prioritas, Desa Sukadiri, APBDes

THE DYNAMICS OF VILLAGE FUND MANAGEMENT AND PRIORITY BASED DEVELOPMENT IN THE FORMULATING OF APBDes

Abstract
Enactment of Village Law No. 6/2014
opens opportunities for villages to
accelerate their development through the
allocation of village funds. Through good
village fund management and based on
the concept of Good Governance, the
efforts will be made to meet the principles
of transparency, participation, and
accountability so that it impacts on their
priorities and needs in village
development. This study tries to analyze
the process of village fund management
with a development planning approach
based on priorities and needs in the
mechanism of formulating the APBDes.
The method used in this research is
descriptive method with a qualitative
approach through data collection
techniques through interviews. The
location of this research focuses on the
development planning carried out in
Sukadiri Village, Tangerang Regency. This
study found that the preparation of the
APBDes was carried out by involving all


elements and aspirations of the community regarding their needs by referring to the RPJMDes so that there would be continuity from the work programs of the village government each year. What is unfortunate is that there is no effort from the Sukadiri Village Government to obtain and increase the village's original income.

Keyword: Viilage Funds, Development Planning, Priority, Sukadiri Village, APBDes

\section{A. PENDAHULUAN}

Diaturnya desa dengan undangundang tersendiri, memperlihatkan pemerintah berniat untuk menjadikan desa sebagai basis pembangunan nasional. Desa sebagai penyelenggara pemerintahan terendah berdasarkan hierarki pelaksana pemerintahan yang memiliki hak otonom yang ada di Indonesia, diharapkan mampu menjadi garda terdepan dalam melakukan pembangunan, karena desa dianggap sebagai elemen dasar yang secara langsung berinteraksi dengan masyarakat. Pemerintah Desa merupakan suatu kesatuan pelaksana pemerintahan yang memiliki tanggung jawab untuk mewujudkan kedaulatan desa.

Selama ini Otonomi desa dianggap adalah "otonomi sebenarnya" dalam hal ini berarti tidak hanya desa memiliki kewenangan dalam hal mengurus rumah tangganya sendiri, tetapi juga dalam berinteraksi sosial diikat oleh norma dan nilai yang hidup dan tumbuh dalam masyaraka. Pada masa kepemimpinan Orde Baru, pemberlakuan homogenisasi bagi desa semakin menghilangkan nilainilai otonomi desa. Di bawah kekuasaan Orde Baru pengawasan dan kontrol otoritas yang lebih tinggi dan struktur desa dilemparkan dalam satu tunggal struktur administrasi yang dirancang oleh pemerintah pusat (Antlöv, 2003; Antlöv, Wetterberg, \& Dharmawan, 2016; Bebbington, Dharmawan, Fahmi, \& Guggenheim, 2006).

Pasca peristiwa reformasi dan tumbangnya rezim orde baru di tahun 1998, keinginan dan ide-ide untuk mengembalikan otonomi desa kepada nilai otonomi yang sebenarnya mulai muncul. Tetapi kemudian permasalah lain muncul seiring dengan ide untuk mengembalikan fungsi otonomi desa, yaitu tuntutan untuk mencapai kesejahteraan desa. Sistem pemerintahan desa yang memiliki keberagaman sistem antara desa yang satu dengan yang lain, sehingga setiap desa memiliki karakternya sendiri yang kadang justru menghambat alur kontrol untuk perbaikan dan kesejahteraan (Bebbington, Dharmawan, Fahmi, \& Guggenheim, 2004; Bebbington et al., 2006).

Undang-Undang Nomor 6 Tahun 2014 Tentang Desa hadir sebagai bentuk keseriusan pemerintah guna meningkatkan percepatan pembangunan desa dan meningkatkan pelayanan publik demi kesejahteraan masyarakat. Hal ini mengingat bahwa sebelumnya 
Pemerintahan Desa hanya diatur dalam Undang-Undang Nomor 32 Tahun 2004 Tentang Pemerintahan Daerah.

Di dalam undang-undang desa diatur tentang perlunya menetapkan kaidah-kaidah yang baik dalam menjalankan roda pemerintahan, yang didalamnya berisikan kaidahkaidah dalam bidang pengelolaan pemerintahan untuk mewujudkan tata kelola pemerintahan yang baik (Good Governence). Undang-undang Desa yang baru memberikan keistimewaan tersendiri bagi desa terutama dalam hal pengelolaan keuangan. Seperti selisih jumlah yang signifikan antara dana desa dengan jumlah Alokasi Dana Desa (ADD). Kebijakan anggaran tersebut telah membuka ruang yang lebih luas bagi desa untuk mewujudkan kemandirian desa (Ahrori, 2011; Akbar, 2015;

Astuty, 2013).

Konsep alokasi dana desa (Sumber) Alokasi dana desa yang berasal dari pusat ditujukan guna membantu desa dalam segi pendanaan kegiatan pemerintah desa. Dengan nominal yang cukup besar tersebut desa diharapkan mampu membiayai semua kegiatan pemerintahannya yang bertujuan meningkatkan kesejahteraan masyarakat desa. Melalui pengelolaan dana desa ini diharapkan adanya peningkatan partisipasi dalam rangka pemenuhan kebutuhan masyarakat desa (Antlöv et al., 2016).

Secara keseluruhan, dana desa merupakan upaya untuk meningkatkan pembangunan di desa dan mengurangi ketimpangan. Desa selama ini dikenal erat kaitannya dengan bidang agriculture, yang dalam perspektif ekonomi masih pada level sistem tradisional ekonomi dan berakibat kepada rendahnya nilai tambah/keuntungan dari produksi sehingga lambatnya perkembangan ekonomi dari wilayah/daerah tersebut (Burch \& Goss, 1999). Hal tersebut merupakan sebuah representasi dasar bahwasannya kehidupan desa lebih berpotensi kepada kemiskinan, dan untuk mengatasi hal tersebut pemerintah melakukan berbagai upaya untuk mendorong pembangunan daerah pedesaan. Beberapa studi berargumentasi jika perkembangan urbanisasi yang tinggi diakibatkan karena gagalnya daya tarik daerah pedesaan dalam pembangunan, yang berakibat kepada Disparitas ekonomi dan interaksi antara perkotaan dan pedesaan (Akita \& Miyata, 2008; Kanbur \& Zhuang, 2013).

Beberapa studi membuktikan jika Tantangan terbesar kegagalan pembangunan di desa, sebagian besar dikarenakan gagalnya membangun manajemen yang efektif dan berkelanjutan serta konsistensi dalam konteks kelembagaan (Martin \& Sherington, 1997; Molosi-France \& Dipholo, 2017; Rodríguez-Pose, 2013). Di dalam Undang-Undang Nomor 6 Tahun 2014 Tentang Desa diatur tentang perlunya menetapkan kaidah-kaidah yang baik dalam menjalankan roda pemerintahan, yang didalamnya berisikan kaidahkaidah dalam bidang pengelolaan 
pemerintahan untuk mewujudkan tata kelola pemerintahan yang baik termasuk tata kelola keuangan.

Kebijakan anggaran yang terdapat dalam undang-undang desa, telah membuka ruang yang lebih luas bagi desa untuk mewujudkan kemandirian desa. Hal tersebut menjadi salah satu keistimewaan yang ada pada undang-undang desa. Alokasi dana desa yang berasal dari pusat ditujukan guna membantu desa dalam segi pendanaan kegiatan pemerintah desa. Dengan nominal yang cukup besar tersebut desa diharapkan mampu membiayai semua kegiatan pemerintahannya yang bertujuan meningkatkan kesejahteraan masyarakat desa (Noviyanti, Gamaputra, Lestari, \& Utami, 2018).

Tetapi walaupun lahirnya undang-undang tersebut merupakan sebuah harapan baru bagi pembangunan dan perkembangan desa, pemerintah desa harus sadar bahwa dalam pelaksananya, penggunaan dana desa memiliki tanggung jawab perihal pencatatan secara administratif pendapatan asli desa yang semenjak dikeluarkannya undang-undang desa tersebut menjadi sebuah poin utama reseitensi dalam hal prosedural penggunaanya. Sebagaiman seperti yang dikemukakan oleh Lewis (2015) pada penelitian sebelumnya mengenai alokasi dana desa yang secara penerapan kebijakannya dianggap terlalu terburu-buru, dan cenderung tanpa perencanaan yang jelas yang dapat berakibat kepada, apakah pemerintah desa mampu untuk mengelola alokasi dana tersebut . Lebih lanjut lagi, Berdasarkan (Susan \& Budirahayu, 2018).

Undang-Undang No. 6 Tahun 2016 telah mengatur mengenai pengelolaan dana desa dengan berasaskan kepada konsep Good Governance yang mengedepankan transparansi, partisipasi, akuntabilitas dan distribusi informasi yang baik (Moedarlis, 2019), akan tetapi pertanyaan fundamental yang terjadi apakah secara konsep kehidupan social politik masyarakat desa telah memahami konsep tersebut? Merupakan sebuah pertanyaan mendasar yang perlu disadari dalam pengelolaan dana desa. Berangkat dari hal diatas, penelitian ini berupaya untuk memberi gambaran lebih dalam mengenai pengelolaan keuangan desa pasca diberlakukannya undangundang desa, terutama dalam pengoptimalisasian penggunaannya dalam pembangunan desa melalui pendekatan perencanaan pembangunan partisipasi. Peneltian ini berupaya untuk mengeksplorasi lebih dalam mengenai mekanisme perencanaan pembangunan dalam penyusunan APBDes di Desa Sukadiri Kabupaten Tangerang dalam sudut pandang perencanaan melalui penetapan prioritas dan kebutuhan desa dan pelaksanaanya.

\section{B. TEORI (Literature Review)}

Undang-Undang nomor 6 tahun 2014 tentang desa, hadir dengan 
sejumlah keistimewaan salah satunya yaitu alokasi dana desa yang bersumber dari APBN dengan nominal yang sangat besar untuk setiap desanya. Dengan alokasi dana desa yang sangat besar dan otonomi yang diberikan pemerintah Indonesia kepada pemerintah desa, membuat desa dapat menggunakan semua dana tersebut dalam membiayai seluruh kegiatan pemerintahan desa. Namun pemerintah tidak hanya memberikan dana dan membebaskan desa menggunakannya sesuai keinginan mereka. Pemerintah memberikan panduan untuk penggunaan dana tersebut yang ditetapkan dalam Peraturan Menteri Dalam Negeri Nomor 113 Tahun 2014 Tentang Pengelolaan Keuangan Desa khususnya mengenai mekanisme penyusunan APBDesa dijelaskan secara rinci pada Pasal 20 sampai 23 pada tahapan perencanaan dalam pengelolaan keuangan desa. Ini bertujuan agar pembangunan desa lebih terarah dan dalam penggunaan dana tersebut lebih efektif dan efesien (Harigunna \& Arinta, 2018).

Peneliti menggunakan teori mengenai Anggaran Pendapatan dan Belanja Desa atau APBDesa yang dikemukakan oleh (Soleh \& Rohmansjah, 2014) yaitu "Rencana Keuangan Tahunan Pemerintahan Desa yang dibahas dan disetujui bersama oleh Pemerintah Desa dan Badan Permusyawaratan Desa yang ditetapkan dengan Peraturan Desa, yang terdiri dari Pendapatan, Belanja dan Pembiayaan". Berdasarkan pemahaman tersebut, peneliti membagi 3 tahapan dalam mekanisme penyusunan APBDesa yaitu: a) Perencanaan Anggaran Pendapatan dan Belanja Desa atau APBDesa; b) Pendapatan, belanja dan pembiayaan desa; dan c) Penetapan Anggaran Pendapatan dan Belanja Desa atau APBDesa.

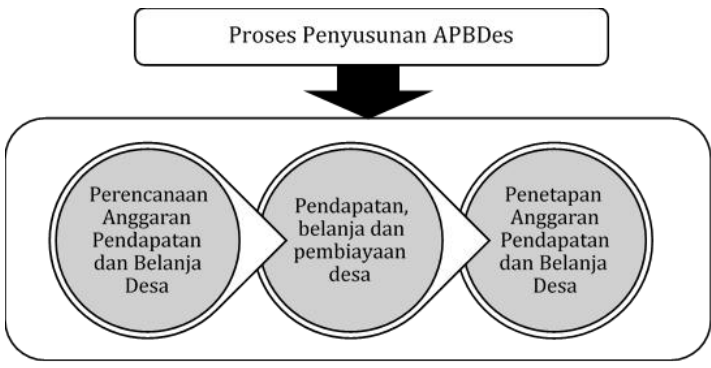

Gambar: Kerangka Pemikiran

Sumber: (Soleh \& Rohmansjah, 2014)

\section{METODE}

Penelitian ini menggunakan metode penelitian kualitatif dengan pendekatan deskriptif. Tujuan dari penelitian ini adalah untuk mengeksplorasi lebih dalam mengenai mekanisme perencanaan pembangunan Desa Sukadiri Kabupaten Tangerang dalam sudut pandang perencanaan melalui penetapan prioritas dan kebutuhan desa dan pelaksanaanya. Dalam penelitian ini, proses pengumpulan data dilakukan dengan wawancara mendalam dengan berpedoman kepada teori dari (Soleh \& Rohmansjah, 2014) mengenai rencana keuangan tahunan desa.

Teknik wawancara mendalam yang digunakan yaitu peneliti berusaha menggali informasi sebanyak-banyaknya mengenai mekanisme penyusunan APBDesa 
kepada narasuber yang telah ditentukan sebelumnya. Dalam menentukan informan untuk mendapatkan informasi yang valid peneliti menggunakan teknik purposive sampling. Adapun yang menjadi informan dalam penelitian ini dapat dilihat pada tabel narasumber penelitian di bawah ini.

Tabel 1. Informan Penelitian

\begin{tabular}{|c|c|c|c|}
\hline No & Nama & Jabatan & Tupoksi \\
\hline & Mad & Kepala & Menyelenggarak \\
\hline & Yasin & Desa & an Pemerintah \\
\hline & & Sukadiri & Desa, Pembinaan \\
\hline & & & Masyarakat dan \\
\hline & & & Pemberdayaan \\
\hline & & & Masyarakat. \\
\hline
\end{tabular}

2. Andi Sekretar Membantu

Wijaya is Desa Kepala Desa Sukadiri Dalam

Melaksanakan

Tugas

Dan

Wewenangnya.

3. Ajid Sekretar Menampung dan

S.Pd is Badan Menyalurkan

Permusy Aspirasi

awarata Masyarakat Desa

n Desa dan Melakukan

(BPD) Pengawasan

Kinerja Kepala

Desa.

4. Nunung Masyara

kat Desa

Sukadiri

\section{HASIL DAN PEMBAHASAN}

1. Village Development Planning Management

Pemerintah desa setiap tahun wajib menyusun Anggaran

Pendapatan dan Belanja Desa atau APBDesa. APBDesa merupakan pembiayaan terhadap program pembangunan tahunan yang diselenggarakan oleh pemerintah desa. Program pembangunan tahunan desa diturunkan dari Program Pembangunan Jangka Menengah Desa (RPJMDes) yang merupakan penjabaran visi dan misi kepala desa terpilih. Programprogram tesebut disusun menjadi Rencana Kerja Pemerintah Desa (RKPDes) yaitu rencana kerja tahunan pemerintah desa dalam menyelenggarakan program pembangunan dan pelayanan di suatu desa.

Proses penyusunan APBDesa yang akan peneliti kemukakan di bawah, berdasarkan pada tahapan perencanaan dalam pengelolaan keuangan desa yang tercantum dalam Peraturan Menteri Dalam Negeri Republik Indonesia Nomor 113 Tahun 2014 Tentang Pengelolaan Keuangan Desa pada Pasal 20, 21, 22 dan 23 yaitu sebagai berikut. Proses penyusunan APBDesa dilakukan secara bertahap yang bertujuan untuk mempermudah dan memaksimalkan kegiatan penyusunan APBDes tersebut. Tahapan-tahapan tersebut terdiri dari tahap persiapan, evaluasi dan penetapan APBDesa. Proses penyusunan APBDesa melibatkan semua elemen yang ada di desa sukadiri terutama RT dan RW setempat. Masyarakat dapat menyampaikan aspirasi mengenai kebutuhan mereka kepada RT dan RW setempat, kemudian pada pra musrenbang para RT dan RW tersebut menyampaikan aspirasi 
yang telah ditampung dan memberikan arahan atau pandangan terhadap tim penyusun APBDesa.

Tahap persiapan ialah penyusunan Rancangan Peraturan Desa (Raperdes) tentang APBDesa berdasarkan Rencana Kerja Pembangunan Desa (RKPDes) yang dilakukan oleh sekretaris desa. Raperdes yang telah disusun harus meliputi naskah APBDesa, lampiran 1 ringkasan APBDesa, lampiran 2 rincian APBDesa, lampiran 3 penjabaran APBDesa serta Dokumen Pelaksanaan Anggaran Desa (DPADes). Setelah itu sekretaris desa menyampaikan Raperdes tentang APBDesa kepada kepala desa guna memperoleh persetujuan dari kepala desa.

Raperdes tentang APBDesa yang sudah disetujui oleh kepala desa selanjutnya akan disampaikan kepada Badan Permusyawaratan Desa (BPD) dengan melampirankan beberapa hal yang sudah dijelaskan diatas. Dan untuk selanjutnya, dibahas dalam rangka memperoleh pesetujuan bersama disertai surat pengantar dan nota penjelasan rancangan peraturan desa. Penyampaian Raperdes tersebut paling lambat disampaikan 1 bulan setelah Anggaran Pendapatan dan Belanja Daerah (APBD) kabupaten atau kota ditetapkan sebagai peraturan daerah.

Persetujuan bersama antara kepala desa dengan BPD dilakukan paling lambat seminggu setelah Raperdes tersebut diterima oleh BPD, apabila BPD sampai batas waktu yang sudah ditentukan tidak memberikan persetujuan maka kepala desa akan melaksanakan pendapatan dan pengeluaran paling tinggi sebesar angka APBDesa tahun anggaran sebelumnya untuk membiayai keperluan setiap bulan. Apabila hal tersebut terjadi maka dalam melaksanakan APBDesa tahun sebelumnya, kepala desa terlebih

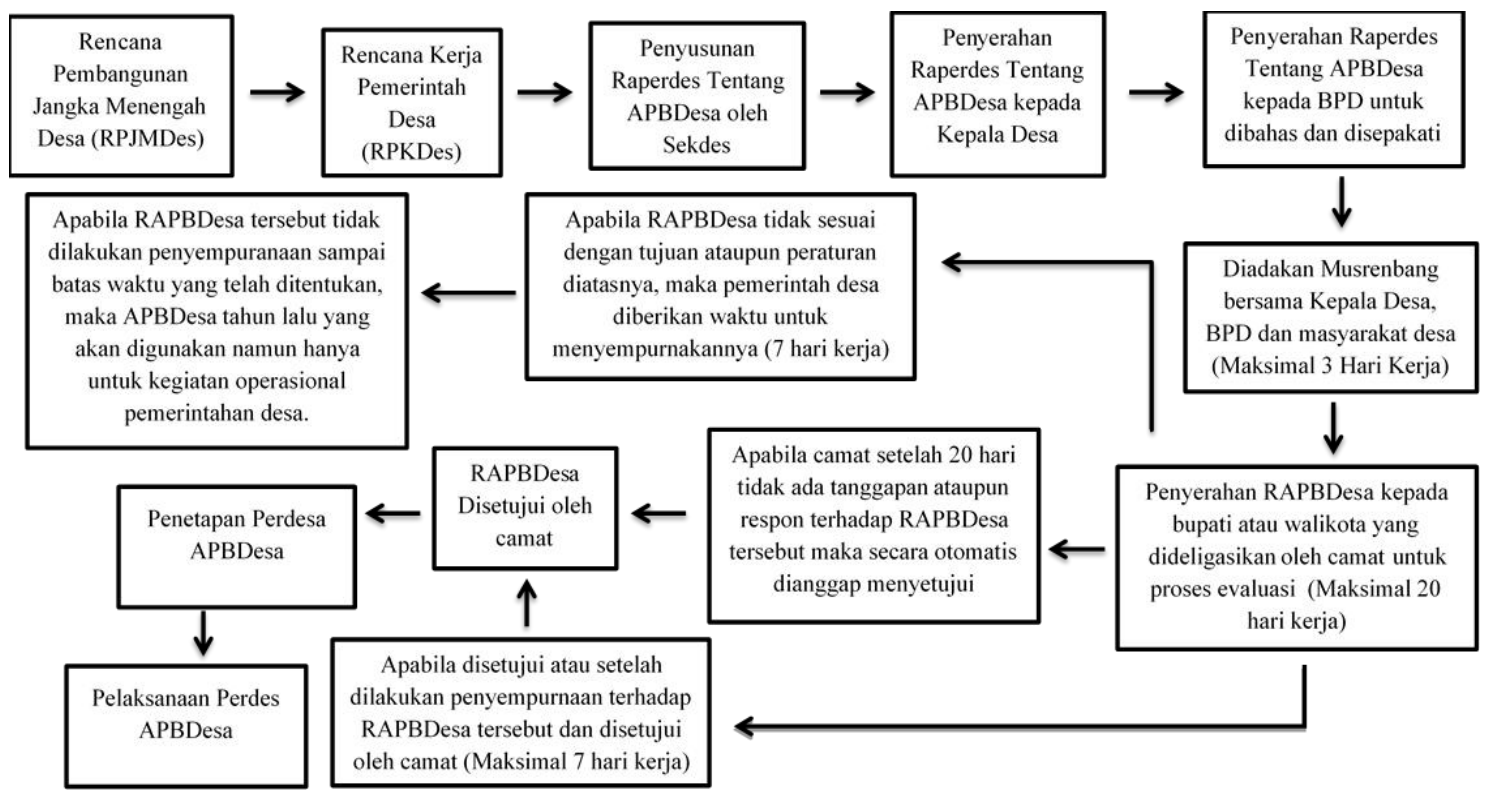

Gambar: Proses Penyusunan APBDes 
dahulu menyusun Raperdes tentang APBDesa dan meminta pengesahan bupati melalui camat.

Raperdes tentang APBDesa yang sudah telah disetujui bersama BPD, sebelum ditetapkan menjadi peraturan desa dilakukanlah proses evaluasi yang dilakukan dengan menyampaikan Raperdes tentang APBDesa tersebut kepada bupati atau walikota melalui atau dideligasikan kepada camat. Hasil evaluasi bupati atau walikota terhadap rancangan peraturan desa tentang APBDesa tentang APBDesa disampaikan paling lama 20 hari kerja kepada kepala desa.

Setelah Raperdes tentang APBDesa tersebut dievaluasi oleh bupati atau walikota melalui camat dan sudah setuju dengan Raperdes tersebut, kepala desa dan BPD melakuka penyesuaian Raperdes tentang APBDesa dan selanjutnya ditetapkan menjadi peraturan desa. Peraturan desa yang telah ditetapkan tersebut selanjutnya dikirim kepada bupati atau walikota bagian pemerintahan desa, dengan tembusan Inspektorat daerah, bagian hukum dan camat.

Dalam perencaaan pembangunan desa sukadiri berusaha untuk menekankan kepada apa yang masyarakat sampaikan mengenai kebutuhan masyarakat, Berdasarkan hal tersebut perencanaan pembangunan yang diterapkan oleh Desa Sukadiri sudah menerapkan mekanisme bottom up planning. Perencanaan dengan metode bottom- up ini berupaya melibatkan semua pihak sejak awal, sehingga setiap keputusan yang diambil oleh Pemerintah Desa Sukadiri merupakan keputusan bersama dan mendorong keterlibatan dan komitmen sepenuhnya untuk melaksanakannya. Perencanaan pembangunan yang dilakukan dengan cara tersebut diharapkan masyarakat ikut serta secara aktif dalam pembangunan desa itu sendiri.

Bottom-up planning merupakan perencanaan yang dibuat berdasarkan kebutuhan, keinginan dan permasalahan yang dihadapi oleh masyarakat desa yang kemudian bersama-sama pemerintah desa menetapkan kebijakan untuk menyelesaikan permasalahan yang sedang dihadapi tersebut. Pemerintah Desa di sini hanya berperan sebagai fasilisator. Sebagaimana yang dikemukakan oleh Sekretaris BPD Sukadiri, bahwa "Pemerintah Desa Sukadiri khususnya para Kaur dan BPD bertugas untuk mengelola dan mengawasi anggaran desa".

Pemerintah Desa dan BPD Sukadiri hanya berperan sebagai alat untuk mengatur dan mengawasi pengelolaan keuangan desa. Meskipun Desa Sukadiri menggunakan perencanaan pembangunan dengan pendekatan Bottom Up Planning dimana semua program kegiatan yang dibuat oleh Pemerintah Desa Sukadiri merupakan hasil representasi dari kebutuhan masyarakat di lapangan, Pemerintah Desa Sukadiri berperan dalam penentuan program yang 
menjadi prioritas. Sedangkan BPD Sukadiri berperan sebagai pengawas bagi Pemerintah Desa dalam mengelola keuangan desa yang bertujuan agar pemerintah desa dapat benar-benar merealisasikan apa yang masyarakat butuhkan sesuai dengan kewenengan Pemerintah Desa. Penampungan asipirasi Masyarakat Desa Sukadiri dilakukan untuk mengetahui semua hal mengenai kebutuhan, keinginan dan permasalahan yang dihadapi oleh masyarakat desa dalam keseharian aktifitas mereka. Pada proses tersebut semua yang disampaikan oleh masyarakat diterima dan ditampung secara baik oleh Pemerintah Desa dan BPD Sukadiri.

Penentuan program-program prioritas dikarenakan anggaran atau keuangan desa yang digunakan untuk membiayai program tersebut memiliki batasan dalam jumlah nominal sehingga tidak dapat merealisasikan semua yang masyarakat sampaikan meskipun hal tersebut merupakan kebutuhan mereka. Dengan menentuan program prioritas diharapkan penggunaan keuangan desa dapat dilaksanakan dengan maksimal dan terarah. Penentuan program prioritas yang akan dianggarkan dalam APBDesa menggunakan

Rencana

Pembangunan Jangka Menengah Desa atau RPJMDes Sukadiri sebagai pedomannya.

Pemerintah Desa Sukadiri menggunakan RPJMDes yang telah dibuat ketika Kepala Desa baru dilantik sebagai pedoman dalam penyusunan APBDesa. Penggunaan RPJMDes sebagai pedoman dalam penentuan program prioritas dapat menghasilkan kegiatan atau programprogram kerja yang saling menopang atau menunjang program-program pemerintah pada tahun sebelumnya dan tahun selanjutnya. Sebagaimana yang tercantum dalam UndangUndang Nomor 6 Tahun 2014

Tentang Desa Pasal 79 Ayat 1 "pemerintah desa menyusun perencanaan pembangunan desa sesuai dengan kewenangannya dengan mengacu pada perencanaan pembangunan kabupaten/kota".

Ini disebabkan RPJMDes dibuat setiap 6 tahun sekali dan berisikan garis besar pembangunan yang akan dilakukan oleh pemerintah desa, sedangkan RKPDes dibuat setiap tahun dan berisikan programprogram yang menunjang garis besar pembangunan yang ada di RPJMDes tersebut. RPJMDes berisikan arah kebijakan pembangunan desa yang disusun berdasarkan keadaan desa dan sebagai tindakan penyelarasan kebijakan pembangunan desa dengan kabupaten atau kota.

Menyinergiskan kebijakankebijakan yang dikeluarkan Pemerintah Desa Sukadiri mengenai pembangunan desa dengan arah kebijakan Pemerintah Kabupaten Tangerang dilakukan agar kebijakankebijakan pemerintah desa yang dirumuskan dalam RKPDes dapat menopang atau mendukung pembangunan yang dilakukan oleh pemerintah kabupaten atau kota dalam hal ini Kabupaten Tangerang. 
Berdasakan hal tersebutlah RPJMDes sangat mempengaruhi penentuan program prioritas di Desa Sukadiri.

Namun tidak dapat dipungkiri bahwa pembangunan di Desa Sukadiri lebih mengedepankan pembangunan fisik berupa infrastruktur yaitu jalan, hal tersebut merupakan kebutuhan yang paling sering disampaikan oleh masyarakat, sebagaimana yang telah disampaikan oleh Kepala Desa Sukadiri, bahwa "Masyarakat desa lebih menginginkan pembangunan fisik yaitu jalan, sehingga dalam menentukan program prioritas berdasarkan seberapa penting jalan tersebut digunakan dalam keseharian masyarakat desa untuk beraktifitas".

Hal tersebut pula dibenarkan olehSekretaris BPD Sukadiri: "Masyarakat hanya mengingkan pembangunan fisik atau jalan, jadi penentuan prioritas berdasarkan pada letak strategis jalan tersebut ketika digunakan masyarakat dalam aktifitas sehari-hari".

Berdasarkan hasil wawancara tersebut, pembangunan fisik menjadi salah satu program prioritas di Desa Sukadiri ini disebabkan masih banyaknya akses jalan di desa yang sulit untuk dilalui oleh masyarakat desa sehingga menghambat aktifitas mereka sehari-hari. Kesulitan dan keterbatasan yang masyarakat desa alami dapat menghambat kegiatan perekonomian mereka, seperti distribusi hasil pertanian. Desa Sukadiri memiliki luas lahan pertanian yang cukup besar, dan menjadikan pertanian menjadi salah satu sumber utama ekonomi Masyarakat Desa Sukadiri. Infrastruktur desa khususnya jalan menjadi prioritas desa, maka untuk penentuan dimana pembangunan jalan tersebut akan dilakukan letak strategisnya yang menentukan apakah jalan tersebut menjadi prioritas desa yang harus didahulukan.

Secara lebih detail Pada Anggaran Pendapatan dan Belanja Desa (APBDesa) Sukadiri Tahun Anggaran 2016, pendapatan desa yang bersumber dari dana desa (alokasi APBN) sebesar Rp. 650,648,820.00. Sebagian besar pendapatan yang bersumber dari dana desa digunakan untuk membiayai belanja desa pada bidang pembangunan desa yaitu sebesar $\mathrm{Rp}$. 617,104,620.00. Untuk membiayai kegiatan pembangunan jalan desa sebesar Rp. 541,202,620.00 yang terdiri dari belanja barang dan jasa sebesar Rp. 19,200,000.00 yaitu honorarium tim pengelola kegiatan dan tim teknis insfeksi masingmasing sebesar Rp. 7,200,000.00 dan Rp. 12,000,000.00. Serta belanja modal sebesar Rp. 522,002,620.00 untuk membiayai belanja modal pengadaan jalan desa. Pembangunan, pemanfaatan dan pemeliharaan saluran pembuangan air limbah sebesar Rp. 75,902,000.00 yang terdiri dari belanja barang dan jasa sebesar Rp. 1,200,000.00 untuk membiayai honorarium tim pengelola kegiatan dan tim teknis insfeksi masing-masing sebesar Rp. 450,000.00 dan Rp. 750,000.00. 
kemudian belanja modal sebesar Rp. $74,702,000.00$ untuk membiayai belanja modal dan bangunan lainnya.

Belanja bidang pemberdayaan masyarakat hanya sebesar Rp. $33,544,200.00$ yaitu untuk peningkatan kapasitas kelompok tani dalam pengembangan pertanian. Belanja tersebut terdiri dari belanja barang dan jasa sebesar Rp. 9,529,200.00 yaitu sebesar Rp. $192,000.00$ untuk belanja alat tulis kantor, Rp. 752,200.00 untuk belanja fotocopy, cetak dan pengadaan, $\mathrm{Rp}$ 750,000.00 untuk belanja makanan dan minuman rapat, Rp. 4,785,000.00 untuk belanja barang untuk diberikan kepada masyarakat, Rp. 1,500,000.00 untuk belanja pengganti uang transport, Rp. 450,000.00 untuk belanja honorarium tim pengelola kegiatan, Rp. 750,000.00 untuk belanja honorarium tim teknis kegiatan, Rp. 50,000.00 untuk belanja honorarium petugas kebersihan lapangan, Rp. 300,000.00 belanja honorarium narasumber atau istruktur dan Rp. 24,015,000.00 untuk belanja modal yaitu belanja modal pengadaan peralatan dan mesin lainnya

Penentuan program prioritas menjadi hal yang sangat penting dalam penyusunan APBDesa dikarenakan akan menentukan arah dari pembangunan desa itu sendiri. meskipun sudah dilakukan dengan memperhitungkan segala kemungkinan pasti ada saja hambatan atau kendala yang dihadapai khususnya Pemerintah Desa dan BPD dalam pelaksanaanya.
Sekretaris BPD Sukadiri menyampaikan bahwa kendala yang sering dihadapi bukan pada teknis penyusunan APBDesa, melainkan pada masyarakat desa itu sendiri. Masyarakat menginginkan aspirasinya dapat terealisasikan semuanya, sedangkan dana yang tersedia berbandik terbaik dengan banyaknya aspirasi masyarakat. Berdasarkan apa yang telah disampaikan diatas maka kendala atau hambatan yang terjadi ketika penyusunan APBDesa ialah masyarakat desa itu sendiri. Kurangnya pemahaman masyarakat desa mengenai kewenangan yang dimiliki desa khususnya dalam pengelolaan keuangan desa seperti parameter penggunaan dana desa, menyebabkan sering terjadinya kesalahpahaman terhadap persepsi Masyarakat Desa dengan Pemerintah Desa Sukadiri.

Kurangnya

pemahaman Masyarakat Desa Sukadiri mengenai keweangan desa dalam melakukan pengelolaan keuangan desa tersebut disebabkan oleh beberapa hal seperti, rendahnya pendidikan Masyarakat Desa Sukadiri. Sebenarnya untuk tingkat pendidikan di Desa Sukadiri sudah sangat baik, ini karena terdapat Sekolah Dasar, Sekolah Menengah Pertama Bahkan Sekolah Menengah Atas Negeri berada dalam ruang Lingkup Desa Sukadiri.

Rendahnya

pendidikan masyarakat desa sukadiri ini ditujukan kepada para tokoh masyarakat, serta masyarakat lainnya yang sudah berumur yang pada 
masanya tidak memiliki cukup pendidikan. Dan mereka-merekalah yang lebih sering mengikuti kegiatan pemerintah desa seperti pramusrenbang dan musrenbang desa. Hal tersebutpun didukung dengan rendahnya partisipasi para Pemuda-Pemuda Desa Sukadiri untuk lebih ikut serta atau berpartisipasi dalam kegiatan pemerintah desa khususnya pramusrenbang dan musrenbang desa dikarenakan hal tersebut sangat mempengaruhi APBDesa Sukadiri. Serta minimnya informasi yang diberikan oleh pemerintah desa sukadiri mengenai kewenangan desa dalam pengelolaan keuangan desa serta parameter yang digunakan dalam menganggarkan suatu program kerja pemerintah desa.

\section{Pendapatan, Belanja dan Pembiayaan Desa}

Pendapatan desa sebagaimana yang tercantum dalam Peraturan Menteri Dalam Negeri Nomor 113 Tahun 2014 Tentang Pengelolaan Keuangan Desa Pasal 9 "pendapatan desa meliputi semua penerimaan uang melalui rekening desa yang merupakan hak desa dalam 1 (satu) tahun anggaran yang tidak perlu dibayar kembalioleh desa".

Berdasarkan Undang-Undang Nomor 6 Tahun 2014 tentang Desa pendapatan desa bersumber dari a) Pendapatan asli desa; b) Alokasi Anggaran Pendapatan dan Belanja Negara; c) Bagian dari hasil pajak daerah dan retribusi daerah kabupaten atau kota; d) Alokasi dana desa yang merupakan bagian dari dana perimbangan yang diterima kabupaten atau kota; e) Bantuan keuangan dari Anggaran Pendapatan dan Belanja Daerah Provinsi dan Anggaran Pendapatan dan Belanja Daerah kabupaten atau kota; f) Hibah dan sumbangaan yang tidak mengikat dari pihak ketiga; g) Lain-lain pendapatan desa yang sah.

Belanja desa sebagaimana yang tertera pada Peraturan Menteri Dalam Negeri Nomor 113 Tahun 2014 Tentang Pengelolaan Keuangan Desa "belanja desa meliputi semua pengeluaran dari rekening desa yang merupakan kewajiban desa dalam 1 (satu) tahun anggaran yang tidak akan diperoleh pembayarannya kembali oleh desa". Pada UndangUndang Nomor 6 Tahun 2014 Tentang Desa Pasal 74 Ayat 1 bahwa "belanja desa diprioritaskan untuk memenuhi kebutuhan pembangunan yang disepakati bersama dalam musyawarah desa dan sesuai dengan prioritas pemerintah daerah kabupaten/kota".

Belanja Desa Sukadiri dipergunakan untuk membiayai program-program kerja yang sebelumnya telah dirumuskan dalam RKPDes Sukadiri yang telah disesuaikan dengan berpedoman pada RPJMDes Sukadiri sehingga arah dari pembangunan Desa Sukadiri sesuai dengan arah pembangunan pemerintah Kabupaten Tangerang.

Sumber pendapatan Desa Sukadiri yang dipergunakan dalam APBDesa Sukadiri khususnya untuk membiayai pembelanjaan atau belanja Desa Sukadiri hanya 
bersumber dari alokasi dana dari APBN, dana alokasi dari Kabupaten Tangerang serta bagi hasil pajak dan retribusi sehingga dana yang digunakan untuk membiayai belanja desa yang terdiri dari programprogram kerja pemerintah desa yang dirumuskan dalam RKPDes Sukadiri harus dipertanggungjawab secara hukum dengan cara melakukan pencatatan pendapatan dan belanja desa secara administratif.

APBDesa adalah dana alokasi baik dari pusat atau daerah melalui rekening kas desa, kemudian yang berhak mengambilnya ialah kepala desa dengan bendahara, pencatatan dilakukan oleh bendahara, apabila ada kegiatan yang sudah selesai dilakukan, ada SPP (Surat Perintah Pembayaran) dimasukan kwitansi kemudian dicatat siapa penerimanya, siapa yang membayarkannya dan siapa yang mengetahuinya sesuai bidang masing-masing, semua dicatat dalam APBDesa termasuk pajak-pajak yang harus dibayar. Semua kegiatan keuangan desa dikelola melalui aplikasi SISKEUDES atau Sistem Keuangan Desa, namun hanya proses pencatatan penerimaan dan belanja desa yang bersumber dari alokasi dana pusat ataupun daerah.

Kegiatan pencatatan mengenai pendapatan dan belanja desa dilakukan melalui aplikasi SISKEUDES atau Sistem Keunagan Desa, alpikasi ini dikembangkan oleh Badan Pengawasan Keuangan dan Pembangunan (BPKP) dalam rangka meningkatkan kualitas tata kelola keuangan desa secara efektif dan efesien serta untuk membantu pemerintah desa dalam melakukan pelaporan mengenai keuangan desa mereka. Kepala Desa Sukadiri juga menyampaikan mengenai proses pencatatan pendapatan dan belanja desa adalah a) untuk kegiatan pencatatan tersebut dilakukan oleh sekretariat desa mengenai pemasukan dan pengeluaran desa yaitu bendahara desa. proses pencairan dana untuk pembayaran atau membiayai program yang tertera pada RKPDes dilakukan dengan adanya rekomendasi saya untuk pencairan sejumlah dana sesuai dengan yang tertera pada RKPDes kemudian diberikan kepada bendahara desa yang selanjutnya uang tersebut dapat dicairakan dari rekening desa dan dapat digunakan untuk membiayai program kerja tersebut; b) Penggunaan anggaran desa khususnya mengenai pencairan sejumlah uang yang dilakukan untuk membiayai program desa yang sudah tercantum dalam RKPDes harus dilakukan dengan baik dan sesuai dengan prosuder pencairan dana tersebut seperti mengumpulkan datadata atau bukti-bukti hasil transaksi seperti kwitansi pembelian, dokumentasi kegiatan dan lain sebagainya mengenai pembayaran hal-hal yang dibutuhkan dalam kegiatan tersebut. hal tersebut dilakukan untuk membantu dalam proses pertanggungjawaban serta laporan keuangan desa itu sendiri. Sebagaimana yang telah disampaikan oleh Kepala Desa dan Sekretaris Desa Sukadiri diatas. 
Pembiayaan desa menurut Peraturan Menteri Dalam Negeri Nomor 113 Tahun 2014 Tentang Pengelolaan Keuangan Desa Pasal 18 Ayat 1 "pembiayaan desa meliputi semua penerimaan yang perlu dibayar kembali dan/atau pengeluaran yang akan diterima kembali, baik pada tahun anggaran yang bersangkutan maupun pada tahun-tahun anggaran berikutnya". Sedangkan pada Ayat 2 pembiayaan desa terdiri dari "penerimaan pembiyaan dan pengeluaran pembiyaan". Penerimaan pembiayaan desa dalam Peraturan Menteri Dalam Negeri Nomor 113 Tahun 2014 Tentang Pengelolaan Keuangan Desa terdiri dari Pasal 18 Ayat 2 "Sisa lebih perhitungan anggaran (SiLPA) tahun sebelumnya, Pencairan dana cadangan, dan Hasil penjualan kekayaan desa yang dipisahkan". Serta Pasal 19 Ayat 1 Pengeluaran pembiayaan desa terdiri dari "pembentukan dana cadangan dan penyertaan modal desa".

Desa Sukadiri hanya memiliki penerimaan pembiayaan yang berasal dari SILPA atau Sisa Lebih Perhitungan Anggaran. Hal tersebut dapat terjadi disebabkan dalam menganggarkan sejumlah uang untuk membiayai program kerja seperti pembeliaan barang pokoknya ditentukan berdasarkan harga tertinggi dipasaran, kemudian ketika prosesnya pemerintah desa dapat melakukan negosisi kepada penyedia barang mengenai harga barang pokok tersebut. Apabila pemerintah desa dapat melakukan negosiasi dan mendapatkan keuntungan material dari hal tersebut, maka keuntungan tersebut dikembalikan ke kas desa dan menjadi SILPA pada tahun tersebut dan akan dimasukan kembali atau dianggarkan pada tahun selanjutnya.

Berdasarkan undang-undang desa, bahwa pendapatan desa tidak hanya bersumber dari alokasi dana dari pemerintah diatasnya melainkan juga didapatkan dari pendapatan asli desa. Pendapatan asli desa dalam Peraturan Menteri Dalam Negeri Nomor 113 Tahun 2014 Tentang Pengelolaan Keuangan Desa Pasal 9 Ayat 3 terdiri atas "hasil usaha, hasil aset, swadaya, partisipasi dan gotong royong, dan lain-lain pendapatan asli desa".

Berbeda dengan pendapatan desa yang bersumber dari dana alokasi, pendapatan asli desa tetap dilakukan pencatatan secara administratif namun tidak menggunakan SISKEUDES sebagaimana yang dilakukan pada pendapatan desa yang bersumber dari dana alokasi. Hal itu terjadi karena pendapatan tidak dituntut secara hukum dalam pertanggungjawabkannya meskipun itu dapat terjadi apabila terjadi penyalahgunaan penggunaan anggaran dari pendapatan asli desa tersebut. Pertanggungjawaban pendapatan asli desa lebih menekankan pada moralitas pemerintah desa, sebab dana yang bersumber dari pendapatan asli desa merupakan hasil kerja keras masyarakat Desa Sukadiri itu sendiri. 
Desa Sukadiri sendiri tidak memiliki pendapatan asli desa, oleh karena itu dana atau anggaran yang digunakan untuk membiayai program-program kerja permeintah desa dibiayai oleh alokasi dana dari pusat dan daerah. Salah satu penyebab tidak adanya pendapatan asli desa di Desa Sukadiri dikarenakan tidak adanya Badan Usaha Milik Desa atau BUMDes. Meskipun begitu Desa Sukadiri masih memiliki kelompok-kelompok usaha seperti kelompok usaha tani. Namun kelompok-kelompok tersebut tidak menyetorkan pendapatan atau hasil yang mereka dapatkan kepada pemerintah desa, melainkan dibagikan kepada para anggotaanggotanya. Ini disebabkan meskipun kelompok-kelompok usaha tersebut berada di Desa Sukadiri dan dikelola oleh masyarakat Desa Sukadiri sendiri namun bukan kepemilikan atau aset Desa Sukadiri. Sehingga Pemerintah Desa Sukadiri tidak memiliki wewenang untuk memperoleh dana dari kelompokkelompok usaha tersebut.

Pendapatan asli desa yang bersifat pungutan-pungutan yang dilakukan oleh pemerintah desa hanya bersifat temporer atau sementeara. Contoh kasusnya yaitu ketika desa membutuhkan lahan untuk Tempat Pemakaman Umum atau TPU secara mendadak ketika APBDesa sudah berjalan separuh jalan, kemudian desa melakukan rapat dengan RT, RW, Pegawai Pemerintah Desa, BPD, Tokoh Masyarakat dan lain sebagainya untuk menyelesaikan permasalahan tersebut. Pemerintah Desa disini hanya sebagai fasilisator sebab pengelolaan uang yang telah terkumpul tersebut bukan berasal dari aparatur desa melainkan tokoh masyarakat yang sudah dipercaya oleh masyarakat.

\section{Penetapan \\ Anggaran \\ Pendapatan dan Belanja Desa}

Penetapan

Anggaran

Pendapatan dan Belanja Desa atau APBDes marupakan proses melegalisasi terhadap APBDes tersebut. Sebelum APBDes dapat digunakan untuk membiayai RKPDes, maka APBDes harus ditetapkan melalui Perdes atau Peraturan Desa. Undang-Undang Nomor 6 Tahun 2014 Tentang Desa Pasal 69 Ayat 3 menjelaskan "Peraturan Desa ditetapkan oleh Kepala Desa setelah dibahas dan disepakati bersama Badan Permusyawaratan Desa". Serta pada Ayat 4 dijelaskan bahwa "Rancangan Peraturan Desa tentang Anggaran Pendapatan dan Belanja Desa, pungutan, tata ruang, dan organisasi pemerintah desa harus mendapatkan evaluasi dari bupati/walikota sebelum ditetapkan menjadi Peraturan Desa".

Upaya yang dilakukan oleh Desa Sukadiri sebagai wujud operasionalisasi dari peraturan dalam Undang-Undang Nomor 6 Tahun 2014 adalah sebelum penetapan RAPBDesa menjadi APBDesa ada Rancangan Peraturan Desa atau Raperdes mengenai penetapan APBDesa, hal pertama ialah kepala desa mengajukan 
Raperdes setelah Rencana Kerja Pemerintah Desa atau RKPDes melalui proses penghitungan dan estimasi dari Kabupaten Tangerang, setelah disetujui maka kepala desa membuat permohonan ke BPD untuk menetapkan Raperdes tersebut menjadi Perdes, Raperdes setelah disetujui di desa dibawa ke kabupaten untuk dievaluasi oleh bupati, setelah itu penetapan dilakukan oleh aparatur desa, BPD dan masyarkat untuk menetapkan APBDesa tahun berjalan.

APBDesa merupakan anggaran yang digunakan pemerintah desa untuk membiayai RKPDes atau Rencana Kerja Pemerintah Desa dan untuk dapat menggunakan anggaran tersebut maka RAPBDesa yang sudah dibuat dan disetujui oleh Pemerintah Desa dan BPD Sukadiri harus ditetapkan menjadi APBDesa melalui Peraturan Desa atau Perdes yang dilakukan oleh Kepala Desa Sukadiri.

Sebelum melakukan penetapan melalui perdes, Kepala Desa mengajukan Raperdes mengenai penetapan APBDesa kepada BPD untuk disepakati bersama. Setelah Raperdes disetujui untuk sepakati oleh BPD, kemudian RAPBDesa yang telah dibuat diajukan atau diserahkan kepada kabupaten untuk dievaluasi. Kegiatan tersebut dapat didelegasikan kepada camat setempat dalam hal ini Camat Sukadiri, untuk melakukan persetujuan mengenai RAPBDesa tersebut. Setelah disepakati oleh bupati melalui camat maka RAPBDesa tersebut dapat ditetapkan bersama Pemerintah
Desa, BPD serta perwakilan Masyarakat Desa Sukadiri melalui Perdes dan secara legal dapat dipergunakan untuk membiayai RKPDes tahun berjalan.

\section{E. SIMPULAN DAN SARAN}

\section{Simpulan}

Mekanisme penyusunan Anggaran Pendapatan dan Belanja Desa atau APBDesa yang dilakukan di Desa Sukadiri Tahun Anggaran 2017 sudah berjalan dengan baik dan mengikuti kaidah-kaidah dalam penyusunan APBDesa yang telah diamanatkan dalam Undang-Undang Nomor 6 Tahun 2014 tentang Desa, sehingga program-program kerja tersebut memiliki suatu arah pembangunan. Desa Sukadiri menggunakan bottom up planning dalam penyusunan APBDesa, dimana dalam menentukan programprogram kerja pemerintah desa berdasarkan apa yang disampaikan masyarakat mengenai kebutuhan, keinginan dan permasalahan yang mereka hadapi dalam keseharian. kemudian, tim penyusun APBDesa yang terdiri dari Kepala Desa, Sekdes, BPD dan seterusnya melakukan penyortiran atau filterisasi mengenai penentuan program prioritas yang akan dianggarkan dalam APBDesa mengingat banyaknya aspirasi masyarakat berbanding terbaik dengan jumlah nominal keuangan di desa. Tim penyusun tersebut merumuskan program prioritas dengan berpedoman pada RPJMDes yang kemudian dirumuskan dalam RKPDes tahun tersebut. 


\section{Saran}

Terdapat beberapa kekurangan mengenai penyusunan APBDesa di Desa Sukadiri, hal tersebut yaitu mengenai pendapatan asli desa dan upaya-upaya dalam peningkatan pendapatan asli desa. Sebagaimana yang peneliti jelaskan pada hasil penelitian bahwasanya Desa Sukadiri tidak memiliki pendapatan asli desa yang dapat digunakan sebagai sumber APBDesa. Pemerintah desa hanya menggunakan alokasi dana dari pemerintah diatasnya dan retibusi hasil pajak sebagai sumber APBDesa. Padahal peningkatan pendapatan asli desa juga merupakan tujuan dari pemerintah pusat membantu keuangan desa dengan alokasi dana dari APBN tersebut.

Kurangnya pemahaman masyarakat desa mengenai kewenangan desa dalam mengelola keuangan desa serta parameter yang digunakan dalam penggunaan keuangan desa tersebut juga menjadi permasalahan yang sering dihadapi oleh Pemerintahan Desa Sukadiri dalan penyusunan APBDesa. Saran yang dapat peneliti kemukakan mengenai penelitian ini adalah mendirikan atau membuat program mengenai Badan Usaha Milik Desa atau BUMDes di Desa Sukadiri untuk meningkatkan sumber pendapatan asli desa; melegalkan pungutanpungutan yang dilakukan Desa Sukadiri sebagai salah satu sumber pendapatan asli desa; melakukan menejerial yang berkelanjutan mengenai program-program pemerintah desa perihal pembedayaan masyarakat khususnya yang bersifat ekonomis, sehingga program tersebut tidak habis begitu saja tanpa memberikan impact atau dampak terhadap Masyarakat Desa Sukadiri dan Desa Sukadiri itu sendiri sebagai sumber pendapatan asli desa; Pemerintah Desa Sukadiri memberikan sosialisasi kepada masyarakat desa mengenai kewenangan desa dalam pengelolaan keuangan, serta parameter yang digunakan dalam penggunaan keuangan desa tersebut.

\section{DAFTAR PUSTAKA}

Ahrori, A. (2011). Partisipasi masyarakat dalam penyusunan APBDes (Studi tentang pola hubungan pemerintah desa dan masyarakat desa Pucangsari kecamatan Purwadadi kabupaten Pasuruan) (PhD Thesis). University of Muhammadiyah Malang.

Akbar, D. L. (2015). Peran Pemerintahan Desa Dalam Penyusunan APBDEs Perspektif Undang-Undang Nomor 6 Tahun 2014 Tentang Desa (Studi di Desa Kedungkelor Kecamatan Warureja Kabupaten Tegal) (PhD Thesis). UNIVERSITAS NEGERI SEMARANG.

Akita, T., \& Miyata, S. (2008). Urbanization, educational expansion, and expenditure inequality in Indonesia in 1996, 1999, and 2002. Journal 
of the Asia Pacific Economy, 13(2), 147-167.

Antlöv, H. (2003). VILLAGE GOVERNMENT AND RURAL DEVELOPMENT IN

INDONESIA: THE NEW DEMOCRATIC FRAMEWORK. Bulletin of Indonesian Economic Studies, 39(2), 193214.

https://doi.org/10.1080/0007 4910302013

Antlöv, H., Wetterberg, A., \& Dharmawan, L. (2016). Village Governance, Community Life, and the 2014 Village Law in Indonesia. Bulletin of Indonesian Economic Studies, 52(2), 161-183. https://doi.org/10.1080/0007 4918.2015.1129047

Astuty, E. (2013). Akuntabilitas Pemerintah Desa dalam pengelolaan Anggaran Pendapatan dan Belanja Desa (APBDES)(Studi pada Alokasi Dana Desa Tahun Anggaran 2011 di Desa Sareng Kecamatan Geger Kabupaten Madiun). Publika, 1(2).

Bebbington, A., Dharmawan, L., Fahmi, E., \& Guggenheim, S. (2004). Village politics, culture and community-driven development: Insights from Indonesia. Progress in Development Studies, 4(3), 187-205. https://doi.org/10.1191/1464 993404ps085oa

Bebbington, A., Dharmawan, L., Fahmi, E., \& Guggenheim, S.
(2006). Local Capacity, Village Governance, and the Political Economy of Rural Development in Indonesia. World Development, 34(11), 1958-1976.

https://doi.org/10.1016/j.wor lddev.2005.11.025

Burch, D., \& Goss, J. (1999). Global Sourcing and Retail Chains: Shifting Relationships of Production in Australian Agrifoods 1. Rural Sociology, 64(2), 334-350.

Harigunna, T., \& Arinta, O. (2018). Penentuan Prioritas Program Kerja Pada Anggaran Pendapatan dan Belanja Desa Menggunakan Metode Analytical Hierarchy Process. Retrieved.

Kanbur, R., \& Zhuang, J. (2013). Urbanization and inequality in Asia. Asian Development Review, 30(1), 131-147.

Lewis, B. D. (2015). Decentralising to villages in Indonesia: Money (and other) mistakes. Public Administration and Development, 35(5), 347-359. Martin, A., \& Sherington, J. (1997).

Participatory research methods-Implementation, effectiveness and institutional context. Agricultural Systems, 55(2), 195-216.

Moedarlis, F. T. (2019). Akuntabilitas Politik dalam Anggaran (Studi Kasus: Dana Gerakan Dusun Membangun (GDM) di Kabupaten Bungo). Journal of 
Government and Civil Society, 3(1), 1-34.

Molosi-France, K., \& Dipholo, K. (2017). Assessing the role of local institutions in participatory development: The case of Khwee and Sehunong settlements in Botswana. Africa's Public Service Delivery and Performance Review, 5(1), 18.

Noviyanti, N., Gamaputra, G., Lestari, Y., \& Utami, D. A. (2018). Pengidentifikasian pendapatan dan prioritas penggunaan dana desa. Publisia (Jurnal Ilmu Administrasi Publik), 3(2), 112.

Rodríguez-Pose, A. (2013). Do institutions matter for regional development? Regional Studies, 47(7), 10341047.

Soleh, C., \& Rohmansjah, H. (2014). Pengelolaan Keuangan Desa. Jakarta: Fokusmedia.

Susan, N., \& Budirahayu, T. (2018). Village Government Capacity in the Implementation of Village Law No. 6 of 2015 in Indonesia. Sustainable Future for Human Security, 17-27. https://doi.org/10.1007/978981-10-5433-4_2 